\title{
The National Commission for the Advancement of Educational Leadership Preparation: \\ An Introduction
}

Michelle D. Young

George J. Petersen

The fall calendar of 2001 was awash in meetings focused on the future of educational leadership. In August of 2001, the Wallace-Reader's Digest Funds sponsored a conference on educational leadership at Manitou Springs, Colorado. In September, the National Commission for the Advancement of Educational Leadership Preparation (NCAELP) planned to hold a meeting on the future of educational leadership preparation, ${ }^{1}$ and in October, the Danforth Foundation, the Land Grant Deans and Affiliated Private Institutions organization, and the U.S. Department of Education focused meetings around educational leadership. Each of these organizations was proactively responding to the increasingly urgent calls for changes in the way educational leadership is practiced and in how educational leaders are prepared and developed (Jackson \& Kelley, 2002 [this issue]; Young, Petersen, \& Short, 2002 [this issue]).

This special issue includes six articles solicited by the NCAELP as thinking pieces for discussion. These articles provided critical examinations of the field of educational administration, including the practice of educational leadership, the preparation and development of educational leaders, the evaluation of programs, and the context within which practice, preparation, and development take place. The special issue also includes two commentary pieces. One commentary, written by Nelda Cambron-McCabe and Luvern L. Cunningham, represents the perspective of educational leadership 
faculty members who have been involved in reform efforts over the past few decades. The second commentary provides a national policy lens from Mike Usdan, an individual who has worked "inside the beltway” on leadership issues for years.

The purpose of this special issue is threefold. One purpose is the articulation and dissemination of information on the NCAELP with our colleagues and those interested in moving our profession forward. A second purpose is to share articles that provide valuable examinations of the current status of our field. The third and final purpose is to encourage a generative discussion on the future of our field, a discussion that has the power to support the reforms needed in educational leadership preparation and professional development.

\section{THE NCAELP}

The NCAELP was established to improve the practice of educational leadership through highquality preparation and professional development. The commission held its first meeting in February of 2002 at the Johnson Foundation's Wingspread Conference Center in Racine, Wisconsin. During this initial meeting, the commission focused its efforts on (a) developing a complex understanding of contemporary contextual factors affecting educational leadership and leadership preparation, (b) examining exceptional and innovative educational leadership preparation and professional development programs, (c) defining clearly and precisely how educational leadership preparation and professional development can support learning-focused leadership, and (d) creating action plans for preparation program change, evaluation, and continual improvement. 
To realize its goals, the NCAELP was designed to facilitate collaboration among key stakeholders. In fact, the commission was developed with the assumption that key to substantive change is collaboration among key stakeholders in the field of educational leadership (e.g., practitioners, school boards, community organizations, businesses, professional organizations, universities, and governmental agencies, among others). Commissioners include leaders in the areas of practice, scholarship, policy, and professional organizations. ${ }^{2}$

Fifteen years ago, the University Council for Educational Administration convened a similar National Commission on Excellence in Educational Administration (NCEEA). This commission was created to improve educational leadership preparation. Through the NCEEA, individuals, organizations, and institutions worked together to analyze educational leadership preparation and to improve preparation and practice. The commission brought national attention to the need for changes in the way school and district leaders are prepared. Specifically, it recommended the following: a redefinition of educational leadership; the establishment of a national policy board related to school leadership, using professional schools as a model for administration preparation; a significant reduction in administrator preparation programs; increased recruitment, preparation, and placement of ethnic minorities and women; the establishment of partnerships with public schools in preparing educational leaders; an increase in the professional development of practicing school leaders; and reform of licensure and certification standards (Forsyth, 1999, p. 75; see also Griffiths, Stout, \& Forsyth, 1988). The NCAELP was developed to build on the work of the NCEEA. 


\section{THE COMMISSIONED ARTICLES}

In support of the NCAELP's efforts, a set of six articles on the state of educational leadership preparation was commissioned. The first article, "The Complexity of Substantive Reform: A Call for Interdependence Among Key Stakeholders,” by Young, Petersen, and Short, focuses on challenges facing educational leadership. Although the authors focus primarily on university preparation programs, they call attention to the role that practitioners, professional organizations, government agencies, and other stakeholders have in the improvement of leadership preparation. According to the authors' analysis, preparation programs in educational leadership as traditionally conceived are no longer adequate. They argue that changes in schools and society require transformations in leadership preparation and to make these transformations, substantive changes are required. Moreover, university programs and key stakeholders must acknowledge that they have similar interests and goals in the preparation of school leaders and recognize that they are connected by an interdependent web that requires collaboration in all aspects of the preparation of school leaders.

The second article, "Reculturing the Profession of Educational Leadership: New Blueprints,” by Murphy, provides an in-depth investigation of the foundations of the educational leadership profession. Murphy discusses the constructs of leadership roles and the discipline-based and practice-based grounding for knowledge in the profession. Murphy focuses on the academic (technical) content as his third construct and then proceeds to reconceptualize the educational leadership profession itself. His goal is to shift from a phenomenon related to "bodies of subject matter" to that of "valued ends." Murphy encourages his readers to focus their attention 
on the central roles of the leader in education. Murphy identifies three such roles: moral steward, educator, and community builder.

In their article "Exceptional and Innovative Programs in Educational Leadership,” Jackson and Kelley describe the past 15 years as full of reform activities. They argue that now is the time for a close reexamination of these reform efforts, and their article takes a large step toward realizing that goal. They identify a number of "lighthouse” programs that are making promising strides and then provide a thought-provoking discussion of why they believe this is the case. Thus, the article not only shares information on effective programs, but it also makes a clear contribution to the conversation around the definition of effectiveness in educational leadership preparation.

The fourth article, “The Professional Development of Principals: Innovations and Opportunities,” by Peterson, views professional development programs as an important and necessary complement to preservice preparation. Although on-the-leadership-job development offers preservice administrators an opportunity to learn some of the requirements of the position, it does not offer prospective administrators the occasion to learn everything about the job prior to practicing. The article offers information about sources of professional development including universities, professional associations, governmental agencies, and not-for-profit organizations. Peterson then analyzes each source, the focus of the programs, their purposes, curriculum, internal coherence, instructional strategies, location, and use of technology. In his analysis, he provides examples of exemplary programs offered by each source.

The fifth article, “Defining Preparation and Professional Development for the Future,” written by 
Grogan and Andrews, examines both preservice preparation and professional development for principals and superintendents. The authors begin with an analysis of how these leadership positions and roles have been conceptualized in the 1980s and 1990s. The authors' summary leads the reader into the current context of heightened criticism and expectations of educational leaders. The authors describe the principal and superintendent as having multiple and complex roles and as key players in the area of collaboration and enhancing professional development. Grogan and Andrews conclude by offering recommendations for preparation and professional development programs.

The sixth article, "Program Self-Evaluation for Continuous Improvement," written by Glasman, Cibulka, and Ashby, provides an analysis of significant internal and external incentives and disincentives for conducting self-evaluations of leadership preparation and professional development programs. Responding to calls for evaluation, the authors provide a self-evaluation model for program improvement anchored in the outcome-based standards recently recommended by the National Council for Accreditation of Teacher Education, which are based on the Interstate School Leaders Licensure Consortium's Standards for School Leaders. The model is presented in three phases. The first phase converts each model standard into specific questions with corresponding procedures for data collection. The second phase suggests ways of summarizing the data about individual candidates, the entire cohort, and each outcome-based standard. The final phase suggests a set of procedures needed for effective implementation. The article concludes with a call for alignment of leadership program components with clear and pertinent outcomes-based standards. 


\section{COMMENTARIES}

The commentaries in this special issue provide a candid appraisal of the cogency and significance of the commissioned articles. Although the authors of both commentaries agree that the work of the commission is important and timely, they diverge on the degree, intensity, and promise of the proposed reform offered in these articles and the work of the commission. The commentary by Usdan articulates serious reservations concerning the capacity of higher education to substantively respond to the current exigency in preparing quality leaders for today’s schools. Usdan believes the commissioned articles provide some useful ideas, but because they confine themselves to the context, values, and expectations of higher education and because they do not convey an adequate sense of urgency or passion about the needed changes, the articles fall short of the mark. In closing, he muses whether educational administration programs have the wherewithal to reform and renew themselves rapidly enough to survive and actually make change happen.

Cambron-McCabe and Cunningham approach the articles with measured optimism and suggest that the work of the commission holds promise for positive and constructive change. They believe that to date, there has not been enough earnest consideration of the importance of interdependent collaboration from all stakeholders to achieve a common agenda and set of goals around improving the preparation of educational leaders. The authors draw parallels between the proposed reform of the commission articles and lessons they learned as members of the national advisory board for the Danforth Foundation's Forum for the American School Superintendent. These parallels lead the authors to suggest that our profession is faced with a lack of activism focused on improving outcomes for children and society and a profound disconnect between higher 
education and practice.

\section{MOVING FORWARD}

Collectively, the six articles and two commentaries assess social, institutional, and professional conditions that reflect on the complexity involved in providing quality leadership preparation. These articles comprise a reflection of today's conditions and suggest first steps to attend to existing problems within our field. Specific and substantive ideas presented in these articles and observations made in the two commentaries require additional in-depth conversations, particularly around the notion that educational leadership is a process of growth and change.

As the articles conscientiously argue, recognition of the interdependence of our field and the need for collaboration is critical to move our profession forward. The roles and expectations of educational leaders and their preparation have become quite complex and political in nature. Yet, the underlying outcome is the future and quality of educational leaders for our nation's schools. Without collaboration today, no common vision can be developed regarding what preparation and development must involve if we are to ensure that all children are afforded a quality educational experience. And without a common vision, we will have a lose-lose situation. Program reform will continue to be fragmented and misguided. The current challenges put forth to preparation programs are essential:

1. We need clearly defined and widely accepted leadership goals for our programs.

2. We need effective delivery structures and organizational processes to enhance individual and 
program-wide outcomes.

3. We need evaluative systems based on outcome-related standards that lend themselves to program enhancement.

4. We need meaningful and sustained collaboration among key educational leadership stakeholders.

The six articles were commissioned for specific purposes and therefore do not deal with a number of issues that are considered important by others in our field. However, the articles in this special issue, as a group, should be viewed as an initial step in the direction of understanding how we might collaboratively take action toward the improvement of educational leadership preparation, to benefit all of the children in our schools.

\section{NOTES}

1. In the aftermath of the September 11th tragedies, this meeting was rescheduled for February 2002.

2. For a complete list of commissioners and participants in the Wingspread meeting, please visit the National Commission for the Advancement of Educational Leadership Preparation Web site at www.ncaelp.org. 


\section{REFERENCES}

Forsyth, P. B. (1999). Redesigning the preparation of school administrators: Toward consensus. In S. D. Thompson (Ed.), School leadership: A blueprintfor change (pp. 71-92). Thousand Oaks, CA: Corwin Press.

Griffiths, D. E., Stout, R. T., \& Forsyth, P. B. (Eds.). (1988). Leaders for America's schools. Berkeley, CA: McCutchan.

Jackson, B. L., \& Kelley, C. (2002). Exceptional and innovative programs in educational leadership. Educational Administration Quarterly, 38, 192-212.

Young, M. D., Petersen, G. J., \& Short, P. M. (2002). The complexity of substantive reform: A call for interdependence among key stakeholders. Educational Administration Quarterly, $38,137-175$. 